\title{
Early complication after total knee arthroplasty in a haemophilia A patient
}

\section{Wczesne powikłanie po endoprotezoplastyce stawu kolanowego u chorego na ciężką hemofilię $A$}

\author{
Paweł Ambroziak' ${ }^{1}$, Piotr Żbikowski ${ }^{1}$, Andrzej Kotela ${ }^{1}$, Jerzy Windyga², Ireneusz Kotela ${ }^{1,3}$ \\ ${ }^{1}$ Orthopedic and Trauma Clinic, Central Clinical Hospital of the Ministry of Interior, Warsaw, Poland \\ Head of Department: Prof. Ireneusz Kotela MD, PhD \\ ${ }^{2}$ Department of Disorders of Hemostasis and Internal Medicine, Institute of Hematology and Transfusion Medicine, Warsaw, Poland \\ Head of Department: Prof. Jerzy Indyga MD, PhD \\ 'Faculty of Sciences, Jan Kochanowski University, Kielce, Poland \\ Head of Department: Prof. Ireneusz Kotela MD, PhD
}

Key words: total knee replacement, arthropathy, haemophilia, bleeding, complication.

Słowa kluczowe: endoprotezoplastyka kolana, artropatia, hemofilia, krwawienie, powikłanie.

\begin{abstract}
Total knee replacement in patients with haemophilia A is a challenging procedure with high risk of complications. Due to the massive destruction of the joint and significantly reduced range of motion, total knee replacement should be performed only by a surgeon with high degree of expertise and experience. During the perioperative period, patients require factor VIII (FVIII) replacement therapy supervised by a haematologist, under control of plasma activity levels. Possible early complications include delayed wound healing, soft tissue and joint bleeding, development of pseudoaneurysm and early infection. Once complications occur, prompt detection and introduction of proper treatment is fundamental.
\end{abstract}

\section{Streszczenie}

Endoprotezoplastyka całkowita stawów u chorych na hemofilię A jest operacją trudną i obarczoną dużym ryzykiem wystąpienia powikłań. Z powodu masywnych zmian zwyrodnieniowych i często znacznego ograniczenia zakresu ruchu przed operacją implantacja endoprotezy wymaga dużego doświadczenia operacyjnego. W okresie okołooperacyjnym należy pacjentowi podać koncentrat brakującego czynnika krzepnięcia VIII (factor VIII - FVIII) pod kontrolą jego aktywności w osoczu. Leczenie substytucyjne powinno przebiegać pod ścisłym nadzorem hematologa. Do możliwych wczesnych powikłań operacji należą opóźnienie lub zaburzenia gojenia rany, krwawienie do tkanek miękkich lub stawu, rozwój tętniaka rzekomego, wczesna infekcja. Wystąpienie jednego z wyżej wymienionych powikłań wymaga wczesnego rozpoznania i odpowiedniego leczenia.

\section{Introduction}

Frequent, recurrent joint bleeds in patients with severe haemophilia A (factor VIII plasma activity levels $<1 \mathrm{IU} / \mathrm{dl}$ ) lead to destruction of the joint and rapid development of massive degenerative changes: haemophilic arthropathy. These changes affect not only the articular surface and bone but also the soft tissues of the joint. Synovial fibrosis due to chronic inflammatory changes and a tendency towards antalgic limb positioning cause gradual limitation of range of motion (ROM) - flexion contracture. Reduction of weight bearing of the affected limb leads to muscle atrophy. These changes occur commonly in knee joints, ankles and elbows. Degenerative changes as a result of joint bleeds lead to significant disability [1]. In cases of in- sufficient replacement of deficient clotting factor, advanced arthropathy may be present in the age range 15-25 years. Patients may often need to use crutches or a wheelchair for locomotion. When arthropathy progresses despite treatment and physiotherapy, the only effective way to treat it is total joint arthroplasty [1-3].

Despite specific, precise guidelines for the treatment of patients with haemophilic arthropathy, total knee arthroplasty is performed rarely and only at specialised centres. The problems usually encountered include the lack of clear orthopaedic recommendations, significantly greater risk of complications and difficulties in creating an experienced team (including haematologist, orthopaedic surgeon, anaesthetist and 
physiotherapist). As well as typical risks and potential complications of joint arthroplasty, complications associated with blood clotting can occur. Surgical difficulties are associated with limitations of ROM and abnormal joint and limb axis. Arthropathy often involves more than one joint; hence, proper planning of the sequence of surgical procedures is the key to success. The recommended sequence is to perform hip replacement first, then knee arthroplasty. Choice of the proper implant is also of paramount importance. Stable implant placement often requires additional bone grafting. Implant survival time may be shorter because of weaker bonding to osteoporotic bone. A higher risk of aseptic or septic implant loosening is noticed. Early wound healing problems are another possible complication. To perform this kind of surgical procedure safely it is necessary to create an experienced team to supervise the patient during treatment. Access to a suitably equipped, specialised laboratory is mandatory.

\section{Case report}

A 25-year-old patient suffering from knee arthropathy caused by repetitive joint bleeds in the course of severe haemophilia A was admitted to the Department of Haemostatic Disorders and Internal Medicine of the Institute of Haematology and Transfusion Medicine in Warsaw for preparation for elective total knee replacement. Comorbidities were epilepsy and chronic hepatitis $\mathrm{C}$ virus infection (HCV). Patient height was $178 \mathrm{~cm}$, weight $80 \mathrm{~kg}$ and body mass index (BMI) $25 \mathrm{~kg} / \mathrm{m}^{2}$. Advanced knee arthropathy was associated with severe ROM restriction and pain. Range of motion before surgery: extension deficit $10^{\circ}$, flexion $90^{\circ}$. The joint was stable in the frontal and sagittal planes with correct axis of the limb (Figure 1).

Basic preoperative laboratory tests were correct except for a highly elongated activated partial thromboplastin time (APTT) due to the absence of factor

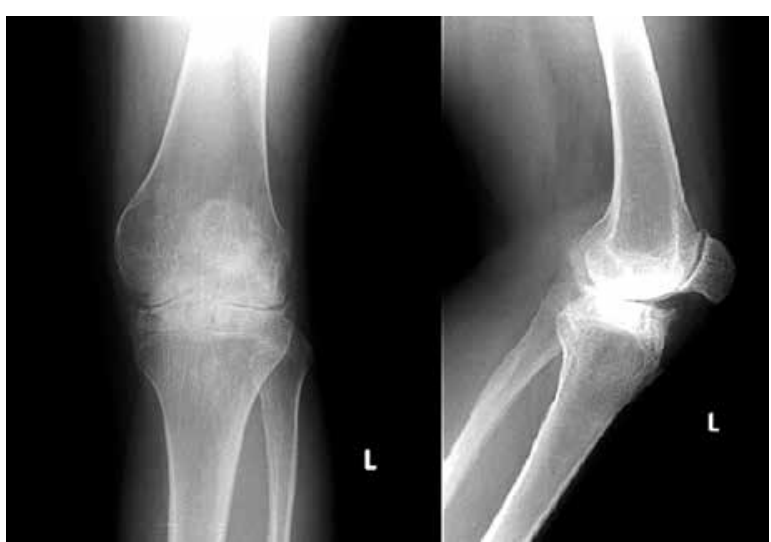

Figure 1. Preoperative X-ray, advanced haemophilic arthropathy
VIII $(<1 \mathrm{IU} / \mathrm{dl})$. The most important laboratory test allowing the patient to elective surgical procedure is the test for the presence of factor VIII inhibitor. In the discussed patient, inhibitor of factor VIII was excluded, so there were no haematological contraindications to elective surgery. Two hours before surgery, factor VIII concentrate was administered at a dose of $50 \mathrm{IU} /$ $\mathrm{kg}$ [1]. Factor VIII plasma activity $30 \mathrm{~min}$ after injection of the concentrate was $104 \mathrm{IU} / \mathrm{dl}$ (normal range 50-150 IU/dl); therefore, inherited deficiency of factor VIII was corrected.

The patient was transferred to the Orthopaedic and Trauma Clinic of the Central Hospital of the Ministry of the Interior to perform total knee arthroplasty. The surgery was performed under general anaesthesia in a typical manner (Figure 2). During the operation patella maltracking was noticed and lateral retinaculum was released. Before closing the wound the pneumatic tourniquet was released and meticulous haemostasis was made. Two drains were left in the wound. In the perioperative period (I-II week) factor VIII plasma activity was maintained at a level above $80 \mathrm{U} / \mathrm{dl}$, and was checked every $24 \mathrm{~h}$ [4]. Thromboprophylaxis was conducted using nadroparin $0.6 \mathrm{ml}$ subcutaneously every $24 \mathrm{~h}$. For the first 4 days, wound bleeding was noticed with no bleeding into the drains. The drains were removed on the second postoperative day.

Physiotherapy was postponed until day 4 , when wound bleeding had stopped. In the following days the correct course of treatment was noticed. An inconsiderable swelling of the knee was present. Narcotic drugs (morphine) were used for analgesia. Non-steroidal, anti-inflammatory drugs were not used due to the potential impact on blood coagulation parameters.

On the $15^{\text {th }}$ day after the surgery slight wound bleeding occurred again, despite maintaining proper FVIII plasma activity $(80 \mathrm{U} / \mathrm{dl})$; therefore, there was no indication for modification of substitution of FVIII [4]. Bleeding was accompanied by increasing

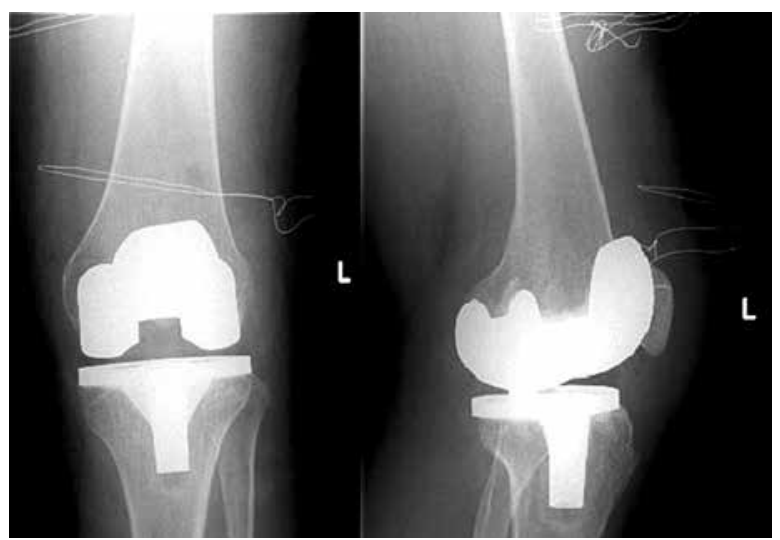

Figure 2. Postoperative X-ray, total knee replacement 
joint swelling. Physiotherapy was discontinued and pressure dressing, ice and limb elevation were introduced. During the next 4 days clinical improvement was not achieved. In order to remove joint haematoma 2 wound stitches were removed. When $150 \mathrm{ml}$ of haematoma was removed, intense pulsating arterial bleeding from the area of the wound bed was noticed. Urgent surgical wound inspection was recommended. Surgery revealed active bleeding from the retinacular artery. The vessel was coagulated and ligated. Additionally, the retinacular area was covered with a haemostatic sponge. A drain was left in the wound. The wound was closed with stitches and a sterile dressing with slight compression was used. FVIII substitution was continued, maintaining its plasma activity at the level of $100 \mathrm{U} / \mathrm{dl}$. Treatment progress after wound revision was typical. The drain was removed on the $3^{\text {rd }}$ day with a total blood loss of $50 \mathrm{ml}$. Intensive physiotherapy was reintroduced, including walking on two crutches with partial weight bearing and ROM exercises. Sutures were removed on the $12^{\text {th }}$ day. The patient was discharged on the $18^{\text {th }}$ day after surgical wound revision in good condition, with $0-70^{\circ} \mathrm{ROM}$ of the operated joint and without swelling or pain. Continuation of the physiotherapy was recommended. Since the wound was healed, physiotherapy was carried out with FVIII administration 3 times a week. The patient remains under outpatient observation

\section{Discussion}

Replacement of deficient clotting factor is necessary when carrying out orthopaedic operations in haemophiliacs. During the perioperative period, patients receive FVIII concentrate intravenously, maintaining its plasma activity at the level of $100 \mathrm{U} /$ $\mathrm{dl}$ within the $1^{\text {st }}$ week, then above $50 \mathrm{U} / \mathrm{dl}$ until the wound is completely healed.

In the case of haemorrhagic complications in the perioperative period, the plasma activity of FVIII should be precisely checked. If the activity is too low, the dose should be increased. Excessive bleeding not responding to factor replacement may indicate the development of factor VIII inhibitor. In cases of this serious complication of substitution the treatment should be modified, replacing FVIII concentrate with by-passing agents $[2,3]$. It should be noted that if the bleeding occurs at the correct level of FVIII plasma activity, "non-haematological" bleeding causes should be sought - for example, surgical causes of bleeding. One has to be sure that nonsteroidal anti-inflammatory drugs are not in use. In cases of persistent oedema [5] in the distant days from surgery, additional tests to confirm the presence of haematoma in the joint or in the surrounding soft tissues, e.g. ultrasound or angiography, should be considered [6-9]. In our patient, the joint swelling was not bigger than expected after this type of extensive surgery; therefore, additional imag- ing was not implemented. Arterial bleeding requires inspection of the wound and its careful closure. An additional, and very useful, method can be angiography with embolisation of the injured vessel [7-9]. In the case described above, active arterial bleeding was revealed during haematoma removal. After exclusion of possible haematological causes of bleeding (proper factor VIII plasma activity, excluding the presence of inhibitor), surgical wound inspection was performed without additional imaging (ultrasound, angiography). It can be stated that the bleeding was the result of an intraoperative vascular injury.

Arterial bleeding in a patient with haemophilia A can occur even with normal plasma activity of clotting factor. Further increases in factor concentrate doses are usually useless and may lead to thrombotic complications. In such cases, surgical intervention and wound inspection is required. There are few reports on complications in the form of a postoperative pseudoaneurysm or persistent joint or soft tissue haematoma [7, 10-15]. The recommended procedure is arteriography with embolisation of the injured vessel or surgical wound inspection and closure of the injured vessel under direct vision.

\section{References}

1. Windyga J, Lopaciuk S, Stefanska E, et al. Haemophilia in Poland. Haemophilia 2006; 12: 52-57.

2. Windyga J, Chojnowski K, Klukowska A, et al. Zasady postępowania w hemofilii A i B. Acta Haematologica Polonica 2008; 39: 537-564.

3. Windyga J, Chojnowski K, Klukowska A, et al. Zasady postępowania w hemofilii A i B powikłanej inhibitorem. Acta Haematologica Polonica 2008; 39: 565-578.

4. Richard KA. Guidelines for therapy and optimal dosages of coagulation factors for treatment of bleeding and surgery in haemophilia. Haemophilia 1995; 1 (Suppl. 1): 8-13.

5. Park JJ, Slover JD, Stuchin SA. Recurrent hemarthrosis in a hemophilic patient after revision total knee arthroplasty. Orthopedics 2010; 33: 771.

6. Bloom AL, Sasson T, Verstandig A, et al. Ultrasoundguided thrombin injection for the treatment of iatrogenic pseudoaneurysm of the femoral artery. Isr Med Assoc J 2001; 3: 649-652.

7. Kickuth R, Anderson S, Peter-Salonen K, et al. Hemophilia A pseudoaneurysm in a patient with high responding inhibitors complicating total knee arthroplasty embolization: a cost-reducing alternative to medical therapy. Cardiovasc Intervent Radiol 2006; 29: 1132-1135.

8. Mauser-Bunschoten EP, Zijl JA, Mali W, et al. Successful treatment of severe bleeding in hemophilic target joints by selective angiographic embolization. Blood 2005; 105: 2654-2657.

9. Rodriguez-Merchan EC, Jimenez-Yuste V. The role of selective angiographic embolization of the musculo-skeletal system in haemophilia. Haemophilia 2009; 15: 864-868.

10. Rodríguez-Merchán EC. Management of the orthopaedic complications of haemophilia. Semin Thromb Hemost 2003; 29: 87-96. 
11. Mann HA, Goddard NJ, Lee CA, et al. Periarticular aneurysm following total knee replacement in hemophilic arthropathy. A case report. J Bone Joint Surg Am 2003; 85A: 2437-2440.

12. Saris DB, van Rinsum AC, Dhert WJ, et al. Periarticular aneurysm formation i haemophilia. Lancet 1997; 349: 766-768.

13. Frauchiger LH, Harstall R, Kajahn J, et al. Bilateral total knee arthroplasty in a patient with haemophilia A, high inhibitor titre and aneurysma spurium of the popliteal artery. Swiss Med Wkly 2010; 140: w13094.

14. Rifaat MA, Massould AF, Shafie MB. Postoperative aneurysm of the descending genicular artery presenting as a pulsating hemartrosis of the knee. J Bone Joint Surg Br 1969; 51: 506-507.

15. Windyga J, Stefanska E, Łopaciuk S, et al. The orthopaedic status of a selected severe haemophilia group. Pol Arch Med Wewn 2005; 113: 562-569.

\section{Address for correspondence:}

Paweł Ambroziak

Orthopedic and Trauma Clinic

Central Clinical Hospital

of the Ministry of Interior

ul. Wołoska 137, 01-912 Warsaw, Poland

Phone: +4822508 1370

E-mail: pawel.ambroziak@wp.pl 